\title{
Dynamic Effect and Control of Key Strata Break of Immediate Roof in Fully Mechanized Mining with Large Mining Height
}

\author{
Yuan Yong, Tu Shihao, Zhang Xiaogang, and Li Bo \\ School of Mines, China University of Mining and Technology, Key Laboratory of Deep Coal Resource Mining, Ministry of Education, \\ China-Australian Mining Research Center, Xuzhou, Jiangsu 221116, China
}

Correspondence should be addressed to Tu Shihao; 826192989@qq.com and Zhang Xiaogang; zxgcumt90@163.com

Received 14 November 2014; Revised 12 March 2015; Accepted 14 March 2015

Academic Editor: Shimin Liu

Copyright (C) 2015 Yuan Yong et al. This is an open access article distributed under the Creative Commons Attribution License, which permits unrestricted use, distribution, and reproduction in any medium, provided the original work is properly cited.

This paper puts forward the concept of key strata in immediate roof (KSIF) and studied the dynamic effect and control mechanism of KSIF. The results show that KSIR controls the caving of its upper immediate roof strata; the break of KSIR has direct dynamic impact on its lower strata and this impact increases along with the increase of the thickness and hardness of the KSIR and the decrease of the distance to the working seam. The KSIR and main roof can easily form the bilayer structure "Cantilever-Masonry beam." Support work load is affected by the position, thickness, and hardness of KSIR. The support work load increased on the condition of increase of the thickness and hardness of KSIR and the decrease of the distance to the face.

\section{Introduction}

In 2013, the coal production in China accounted for almost $1 / 2$ of the total coal output in the world, and its coal production extracted from thick coal seams accounts for $40 \% \sim 50 \%$ of national coal production. However, China is also the country with the largest number of mining disasters in all around the world $[1,2]$. The number of people who died because of coal mine disasters is 1067 , and $30.5 \%$ of those disasters are roof accidents. This situation means that it is quite important to control the mining safety in thick coal seams, especially about the control of roof stability because it significantly affects the safety of mining workers and equipment [3]. The common mining methods for thick coal seam with thickness more than 3.5 meters mining are fully mechanized mining with top coal caving (FMMTCC) and FMMLMH. Practice shows that recovery rates in FMMLMH are 10\% 15\% higher than FMMTCC. In recent years, with the development of mining equipment, FMMLMH technology has been widely applied in thick coal seam mining. As a type of high recovery ratio of mining technology with a promising future, FMMLMH has become a trend for coal seams less than $7.0 \mathrm{~m}$ thick [4].
Many problems exist in FMMLMH face such as large mining and caving height, intense ground pressure, poor coal wall stability, and difficulty in controlling rib spalling, and these problems have hindered the application of FMMLMH technology $[5,6]$.

Scholars have already done much work on roof structure characteristic of fully mechanized face and FMMTCC face, but research on roof structure characteristic of FMMLMH face is not sufficient [7]. Besides, the structure is always considered as a single layer structure of broken main roof. For example, the relation between mining height and caving zone, fractured zone has been studied [8]; analysis on the stability of main roof first break has been performed [9], the relationship between overlying movement and support has been studied [10], and how mining height affects the overlying structure has been analyzed [11]. With the increase of mining height, overlying fractured zone increases and bilayer structure forms in overlying structure have already drawn many scholars interests. Therefore, this paper puts forward the concept of key strata in immediate roof (KSIR) and its discrimination method. Reasonable support work load and dynamic effect of KSIR break have been studied and achieved several beneficial conclusions. 


\section{Dynamic Effect of KSIR in FMMLMH}

2.1. Concept of KSIR. Figure 1 shows the occurrence characteristics of thick coal seams of several mining areas in China. In most cases, mudstone or mudstone strata above coal seam forms immediate roof; the thickness of these strata is almost equivalent to that of the coal seam. Above the immediate roof is the main roof. The overlying caving height increased with the increase of mining height. That is, the overlying caving height can reach $20 \mathrm{~m}$ when the mining height is $6 \mathrm{~m}$. Therefore, under the condition of normal mining height, the break of main roof caves in gob and thus it cannot form a stable structure to bear the overlying weight. The position of stable structure is higher with the increase of mining height which means that, under the condition of normal fully mechanized mining and FMMTCC, the main roof cannot serve its function. Thus, we define that the strata between the stable masonry beam and the coal seam are immediate roof after mining the coal seam; the main roof is the strata that can form stable structure above the immediate roof. The thick hard strata that exist in the immediate roof and control the whole or part of the caving strata in FMMLMH face are KSIR.

\subsection{Discrimination of KSIR}

2.2.1. Discrimination Method and Procedure. The discrimination method of KSIR is based on the definition of KSIR and Key Strata Theory. The derivation procedure of KSIR is shown in Figure 2.

(1) Estimation of Caving Height $H_{k} . H_{k}$ is calculated with the following equation [12] under gently inclined and inclined coal seams:

$$
H_{k}=\frac{M}{K_{k}-1},
$$

where $M$ is mining height, $\mathrm{m} ; K_{k}$ is average coefficients of bulk increase, 1.25 1.5.

(2) Determination of Immediate Roof Height $h_{z} \cdot h_{z}$ is approximate calculated according to the caving height:

$$
h_{z}=H_{k}-\Delta_{z}
$$

where $\Delta_{z}$ is the space height between caving zone and stable structure, 1 3 m [13].

(3) KSIR Positioning. Assuming that immediate roof consists of $n$ strata, based on the definition of immediate roof and article [14], the existence and position of KSIR are determined by the following process.

(1) Positioning the Hard Strata. This step starts with the first immediate roof stratum, from bottom to above, and calculates each stratum according to $E_{m+1} h_{m+1}^{2} \sum_{i=1}^{m} h_{i} \gamma_{i}$ and $\gamma_{m+1} \sum_{i=1}^{m} E_{i} h_{i}^{3}$. If the result is in accord with (3), calculation stops; then from the first layer to the above, the $m+1$ stratum is the first hard stratum. From the first hard stratum, calculation continues with the above method to determine the second hard stratum; the rest can be done in the same method until the topmost hard stratum is positioned. One has

$$
E_{m+1} h_{m+1}^{2} \sum_{i=1}^{m} h_{i} \gamma_{i}>\gamma_{m+1} \sum_{i=1}^{m} E_{i} h_{i}^{3} .
$$

If $m+1>n$, the calculation stops, which means KSIR does not exist; if $m+1 \leq n$, continue the following step.

(2) Examining the Hard Strata to Determine Whether They Are KSIR or Not. According to the concept of KSIR, if there are $j$ strata above the immediate roof deform synchronously, then the load which the $j+1$ stratum imposes on the first hard stratum is

$$
\left.q_{1}\right|_{j}=\frac{E_{1} h_{1}^{3} \sum_{i=1}^{j+1} \gamma_{i} h_{i}}{\sum_{i=1}^{j+1} E_{i} h_{i}^{3}}
$$

where $E_{1}$ and $E_{i}$ are the first and the $i$ immediate roof stratum elasticity modulus, respectively, Mpa; $h_{1}$ and $h_{i}$ are the thickness of the first and the $i$ immediate roof stratum, respectively, $\mathrm{m} ; \gamma_{i}$ is the volume-weight of the $i$ layer, $\mathrm{kN} / \mathrm{m}^{3}$. Consider

$$
\text { If }\left.q_{1}\right|_{j+1}<\left.q_{1}\right|_{j} .
$$

Then the $j(j+m \leqslant n)$ immediate roof stratum is the KSIR, where $\left.q_{1}\right|_{j+1}$ and $\left.q_{1}\right|_{j}$ are the load imposed on the first layer from the calculation of the first layer to the $j+1$ and the $j$ layer.

KSIR does not exist if (5) cannot be established.

2.2.2. Application. The average mining height of No. 15104 working face in Shijiazhuang coal mine, Yangmei group, is $5.5 \mathrm{~m}$. The overlying is mudstone, fine sandstone, and limestone. The caving height is $16.5 \mathrm{~m}$ according to (1) $\left(K_{k}=\right.$ 1.3). Considering deflection of the main roof, $\Delta_{z}=1.5 \mathrm{~m}$; the thickness of immediate roof is $15 \mathrm{~m}$ according to (2). Based on the geogram of No. 15104 face, the immediate roof consists of three layers; their rock mechanics parameters are listed in Table 1. According to the above calculation methods, the second stratum is the hard stratum and also the KSIR.

2.3. Influence of KSIR on Roof Break. Based on No. 15104 face, influence of KSIR on roof break is studied by means of physical modelling.

\subsubsection{Design of Physical Model}

(1) Similar Materials and Their Proportion. The average coal seam thickness and its buried depth are $5.5 \mathrm{~m}$ and $480 \mathrm{~m}$, respectively. Physical dimension of the model is Length $\times$ width $\times$ height $=2.5 \mathrm{~m} \times 0.2 \mathrm{~m} \times 1.3 \mathrm{~m}$. The rest of overlying is replaced by water pressure, $0.06 \mathrm{Mpa}$. Based on the similar laws, geometric similarity ratio is $\alpha_{l}=100$, volume-weight similarity ratio is $\alpha_{r}=1.67$, time similarity ratio is $\alpha_{t}=10$, and intensity similar ratio is $\alpha_{R}=\alpha_{l} \times \alpha_{r}=167$. The main modelling material is sand, and cementing materials are 
TABLE 1: Rock mechanics parameters of 15104 face.

\begin{tabular}{|c|c|c|c|c|c|c|c|}
\hline $\begin{array}{l}\text { Stratum } \\
\text { number }\end{array}$ & Lithology & Thickness/m & $\begin{array}{c}\text { Accumulated } \\
\text { height } / \mathrm{m}\end{array}$ & $\begin{array}{c}\text { Elasticity } \\
\text { modulus/Gpa }\end{array}$ & $\begin{array}{c}\text { Unit } \\
\text { weight } / \mathrm{kN} \cdot \mathrm{m}^{-3}\end{array}$ & $E_{m+1} h_{m+1}^{2} \sum_{i=1}^{m} h_{i} \gamma_{i}$ & $\gamma_{m+1} \sum_{i=1}^{m} E_{i} h_{i}^{3}$ \\
\hline 4 & Packsand & 2 & 17 & 22.8 & 27.1 & 36334.1 & 175286.1 \\
\hline 3 & $\begin{array}{l}\text { Sandy } \\
\text { mudstone }\end{array}$ & 3 & 15 & 7.24 & 26.2 & 20838.2 & 164343.2 \\
\hline 2 & Packsand & 6 & 12 & 22.8 & 27.1 & 129029.8 & 36526.5 \\
\hline 1 & Mudstone & 6 & 6 & 6.24 & 26.2 & & \\
\hline
\end{tabular}

TABLE 2: Modelling material ratio.

\begin{tabular}{|c|c|c|c|c|c|c|c|}
\hline Lithology & $\begin{array}{c}\text { Accumulated } \\
\text { height } / \mathrm{cm}\end{array}$ & $\begin{array}{c}\text { Model } \\
\text { height } / \mathrm{cm}\end{array}$ & $\begin{array}{c}\text { Layer } \\
\text { volume } / \mathrm{cm}^{3}\end{array}$ & $\begin{array}{c}\text { Sand } \\
\text { weight } / \mathrm{kg}\end{array}$ & $\begin{array}{c}\text { Gypsum } \\
\text { weight } / \mathrm{kg}\end{array}$ & $\begin{array}{c}\mathrm{CaCO}_{3} \\
\text { weight/kg }\end{array}$ & $\begin{array}{c}\text { Water } \\
\text { weight } / \mathrm{kg}\end{array}$ \\
\hline Packsand & 140 & 4.5 & 22500 & 32.8 & 3.9 & 2.2 & 4.6 \\
\hline Medium sandstone & 135.5 & 5 & 25000 & 36.4 & 3.6 & 3 & 5.1 \\
\hline Sandy mudstone & 130.5 & 6 & 30000 & 44.6 & 4.5 & 2.6 & 6 \\
\hline Packsand & 124.5 & 4 & 20000 & 29.1 & 3.5 & 1.9 & 4.1 \\
\hline Medium sandstone & 120.5 & 2 & 10000 & 14.6 & 1.5 & 1.2 & 2 \\
\hline Sandy mudstone & 118.5 & 4 & 20000 & 29.8 & 3 & 1.7 & 4 \\
\hline Mudstone & 114.5 & 7.5 & 37500 & 55.8 & 4.8 & 4 & 7.5 \\
\hline Coal & 107 & 1 & 5000 & 7.4 & 0.5 & 0.6 & 1 \\
\hline Sandy mudstone & 106 & 5.5 & 27500 & 40.9 & 4.1 & 2.4 & 5.5 \\
\hline Packsand & 100.5 & 1 & 5000 & 7.3 & 0.9 & 0.5 & 1 \\
\hline Mudstone & 99.5 & 10 & 50000 & 74.4 & 6.3 & 5.3 & 10 \\
\hline Coal & 89.5 & 1.5 & 7500 & 11.2 & 0.8 & 1.0 & 1.5 \\
\hline Sandy mudstone & 88 & 7.5 & 37500 & 55.8 & 5.7 & 3.2 & 7.5 \\
\hline Medium sandstone & 80.5 & 5 & 25000 & 36.4 & 3.6 & 3 & 5.1 \\
\hline Limestone & 75.5 & 3 & 15000 & 21.3 & 2.6 & 2.1 & 3.6 \\
\hline Sandy mudstone & 72.5 & 6.5 & 32500 & 48.4 & 4.9 & 2.8 & 6.5 \\
\hline Packsand & 66 & 5.5 & 27500 & 40.1 & 4.8 & 2.7 & 5.6 \\
\hline Mudstone & 60.5 & 4.5 & 22500 & 33.5 & 2.9 & 2.4 & 4.5 \\
\hline Limestone & 56 & 6 & 30000 & 42.5 & 5.1 & 4.3 & 7.3 \\
\hline Coal & 50 & 1 & 5000 & 7.4 & 0.5 & 0.6 & 1 \\
\hline Sandy mudstone & 49 & 6 & 30000 & 44.6 & 4.5 & 2.6 & 6 \\
\hline Mudstone & 43 & 4.5 & 22500 & 33.5 & 2.9 & 2.4 & 4.5 \\
\hline Limestone & 38.5 & 5 & 25000 & 35.4 & 4.3 & 3.5 & 6.1 \\
\hline Mudstone & 33.5 & 6 & 30000 & 44.6 & 3.8 & 3.2 & 6 \\
\hline Packsand & 27.5 & 2 & 10000 & 14.6 & 1.7 & 1 & 2 \\
\hline Sandy mudstone & 25.5 & 3 & 15000 & 22.3 & 2.3 & 1.3 & 3 \\
\hline Packsand & 22.5 & 6 & 30000 & 43.7 & 5.2 & 2.9 & 6.1 \\
\hline Mudstone & 16.5 & 6 & 30000 & 44.6 & 3.8 & 3.2 & 6 \\
\hline $15 \#$ coal & 10.5 & 5.5 & 27500 & 40 & 4 & 2.6 & 5.2 \\
\hline Sandy mudstone & 5 & 5 & 25000 & 37.3 & 3.6 & 2.5 & 4.7 \\
\hline
\end{tabular}

$\mathrm{CaCO}_{3}$ and gypsum. Mica powder is used between each layer to ensure bed separation. The modelling material ratio of each layer is shown in Table 2.

(2) Model Design and Measurement Point Arrangement. In order to analyze the roof break, stress distribution, and displacement characteristic, seven displacement meters are installed in the fourth and eighth layer, respectively; eleven pressure cells are installed in the fifth and the twelfth layer, respectively. The arrangement is shown in Figure 3. Vertical stress is recorded by pressure cells; vertical displacement is recorded by YHD-50 displacement meters. This record equipment is monitored by TS3890A static resistance strain indicator. 


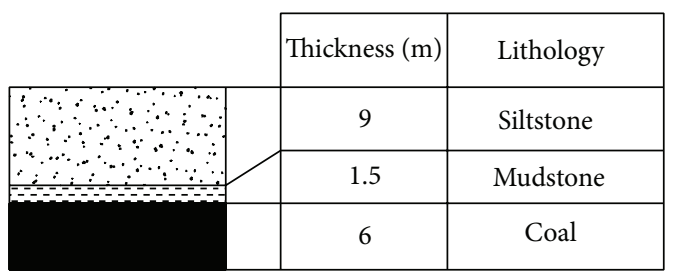

(a) Huaibei mining area

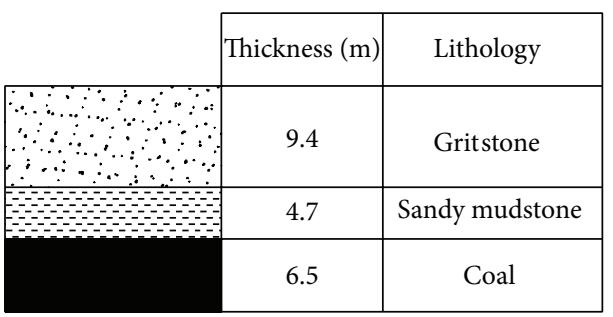

(b) Luan mining area

\begin{tabular}{|c|c|c|}
\hline & Thickness (m) & Lithology \\
\hline \begin{tabular}{lll}
$\because$ & $\ddots$ \\
\hdashline & $\because$
\end{tabular} & 6 & Packsand \\
\hline 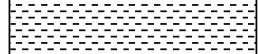 & 6 & Mudstone \\
\hline & 5.5 & Coal \\
\hline
\end{tabular}

(c) Yangquan mining area

\begin{tabular}{|c|c|c|}
\hline & Thickness (m) & Lithology \\
\hline 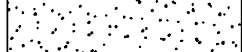 & 7.5 & Packsand \\
\hline & 4 & Sandy mudstone \\
\hline & 0.3 & Calcareous mudstone \\
\hline & 6.6 & Coal \\
\hline
\end{tabular}

(d) Jincheng mining area

FIgURE 1: Typical thick coal seam occurrence characteristics in four mining areas.

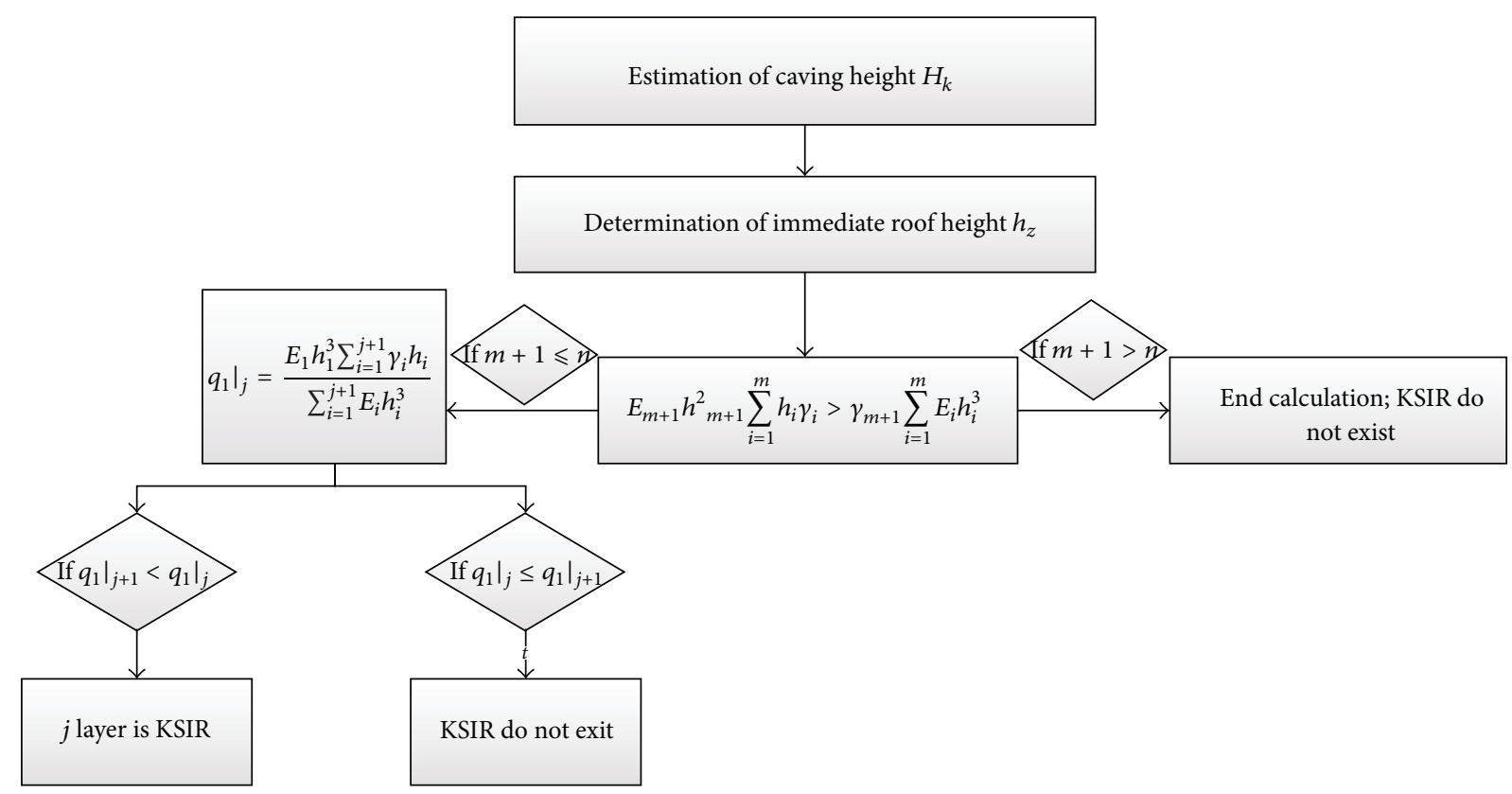

FIGURE 2: Derivation procedure of KSIR.

\subsubsection{Modelling Results Analysis}

(1) Movement Characteristics of Overlying Strata. Figure 4 shows the overlying movement characteristics along with the advancement. Figure 5 shows the height of caving zone and fractured zone along with the advancement.

Conclusions can be drawn from the above as follows. (1) As the face advanced, caving height increased. When the advance distance is $75 \mathrm{~m}$, caving height reached its peak, at approximate of $17 \mathrm{~m}$; layers labeled $3 \sim 6$ are in the caving zone.
Fractured height still increased as the face advanced. When the advance distance is $120 \mathrm{~m}$, fractured height reached its peak, at about $77 \mathrm{~m}$. (2) Layers in caving zone are controlled by KSIR labeled number 4; when the advance distance is $70 \mathrm{~m}$, layers number 5 and number 6 caved along with the break of KSIR and the caving has dynamic impact on the number 3 mudstone layer below the KSIR.

(2) Overlying Displacement Characteristics. Figure 6 shows the vertical displacement characteristics of different roof 


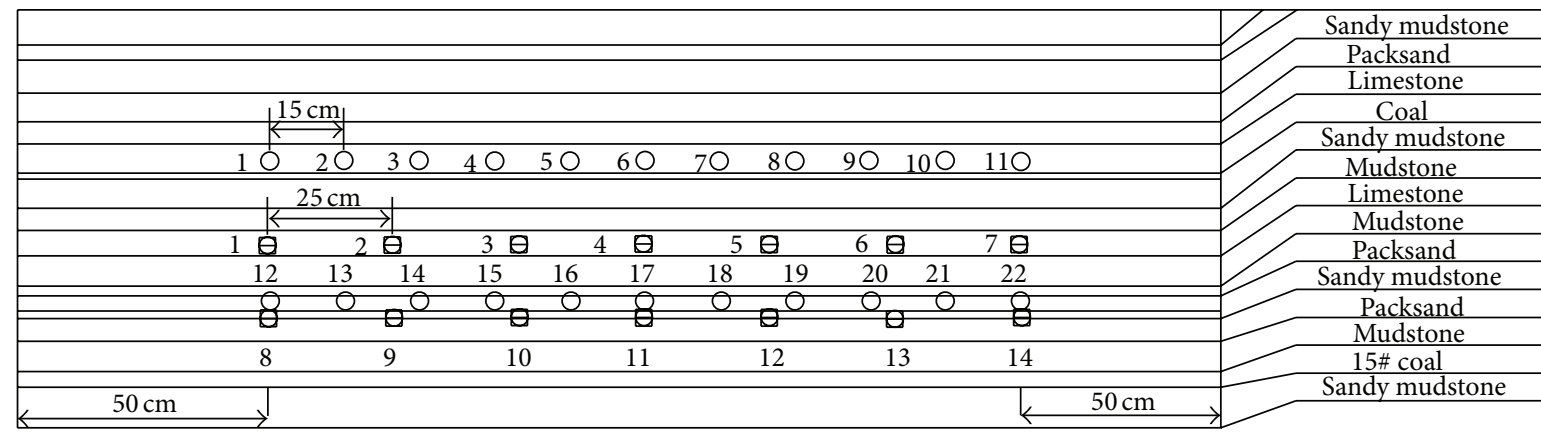

$\rightarrow$ Displacement meter

$\rightarrow$ Pressure cell

FIgURE 3: Model design and measurement point arrangement.

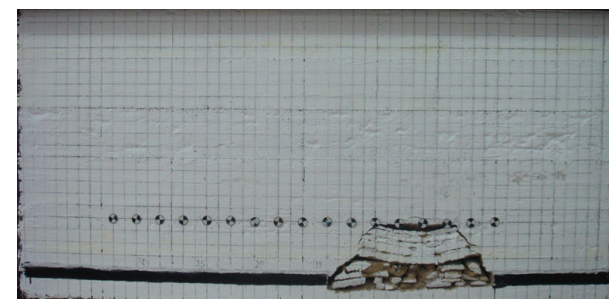

(a) Advancing $70 \mathrm{~m}$

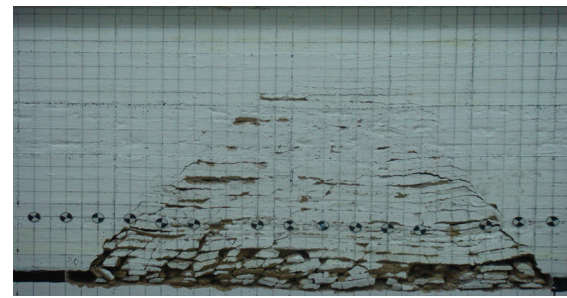

(b) Advancing $150 \mathrm{~m}$

FIGURE 4: Overlying movement characteristics.

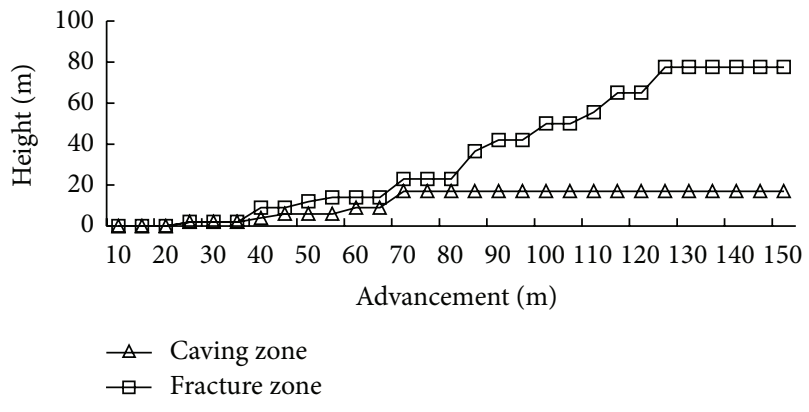

FIGURE 5: Height of caving zone and fractured zone along with the advancement.

layers. According to the figure, vertical displacement shows salutatory increase with the break of roof. The increase intervals of each point are in accord with its layer period break intervals. The displacement of middle measurement points is larger than that of the side points.

(3) Stress Distribution Characteristics. Figure 7 shows the mining-induced stress variation of each measurement point along with the advancement (points numbers 4, 8, 10, 13, and 17 are not included because of malfunction).

According to Figure 7, (1) stress of points numbers 1, 11, 12, and 22 increased with face advancement and the higher the point position is, the larger the increase of the stress is. These points are not in the caving zone; (2) stress of points numbers $2 \sim 9$ increased to the peak and then declined gradually. The peaking period is short. These points are in the fractured zone; (3) numbers 14 21 points are in the caving zone. The stress of these points increased to the peak and then declined gradually. The peaking period is relatively long. For example, stress peaking duration of numbers 16 and 21 points is $20 \mathrm{~m}$ and $10 \mathrm{~m}$, respectively. This is because when KSIR broke, upper layers of numbers 5 and 6 caved into the gob; dynamic impact is strong and lasting.

2.3.3. Effect on Distribution of Abutment Pressure of KSIR. Effect on distribution of abutment pressure of KSIR is studied by means of numerical simulations using $\mathrm{UDEC}^{2 \mathrm{D}} 3.1$. The existence of KSIR, the thickness of KSIR, and the position and hardness of KSIR are simulated to study the abutment pressure distribution with mining height of $5.5 \mathrm{~m}$. According to (1), when mining height is $5.5 \mathrm{~m}$, caving height is about $17 \mathrm{~m}$. In order to facilitate comparison, the thickness of immediate roof and the main roof is $15 \mathrm{~m}$ and $5 \mathrm{~m}$, respectively; the length and height of the models are $200 \mathrm{~m}$ and $56 \mathrm{~m}$, respectively. The buried depth is $480 \mathrm{~m}$. Since the model does not extend to the ground surface, vertical load of $10.85 \mathrm{MPa}$ is applied to the model top to simulate the overburden up to the ground surface. The models are simulated using MohrCoulomb elements. Mechanical properties of each layer are presented in Table 3. 


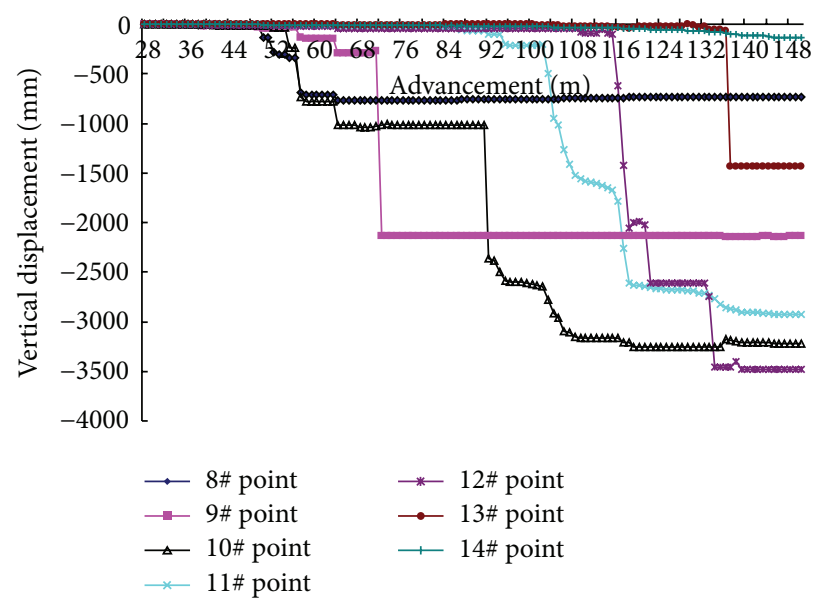

(a) Distance to the roof is $12 \mathrm{~m}$

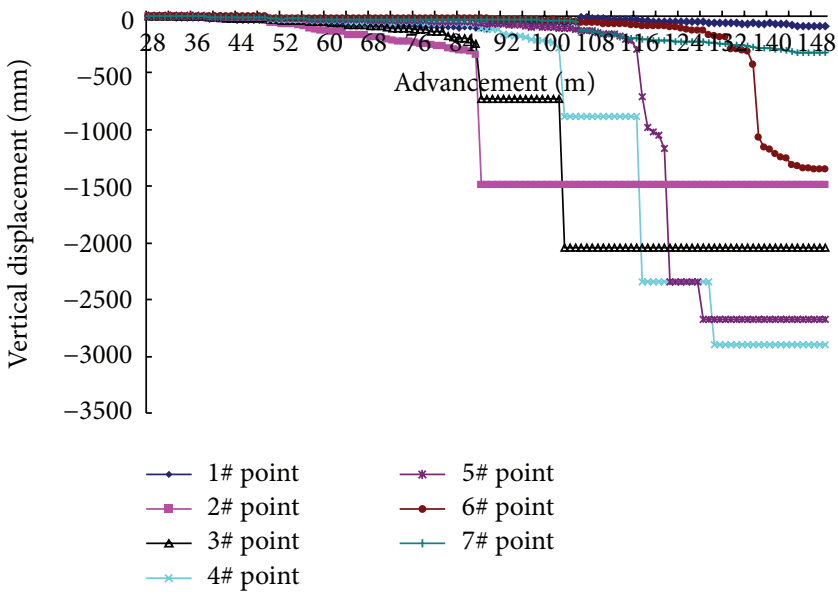

(b) Distance to the roof is $28 \mathrm{~m}$

FIgURE 6: Roof vertical displacement along with advancement.

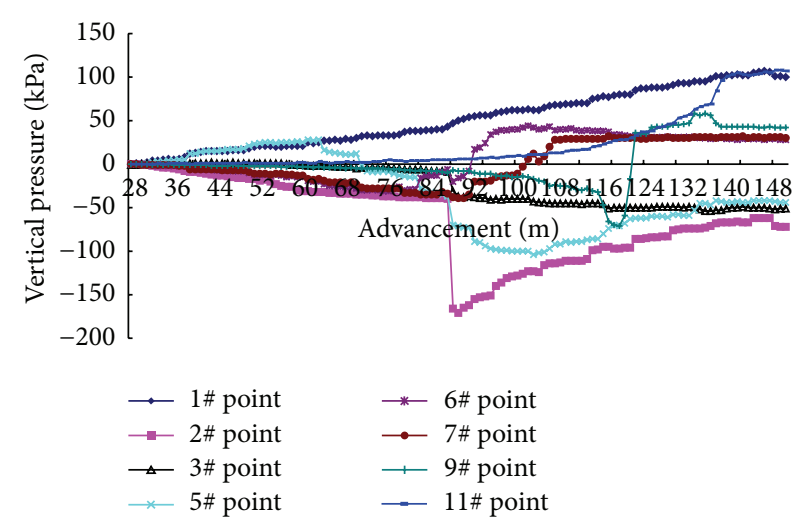

(a) Distance to the roof is $50 \mathrm{~m}$

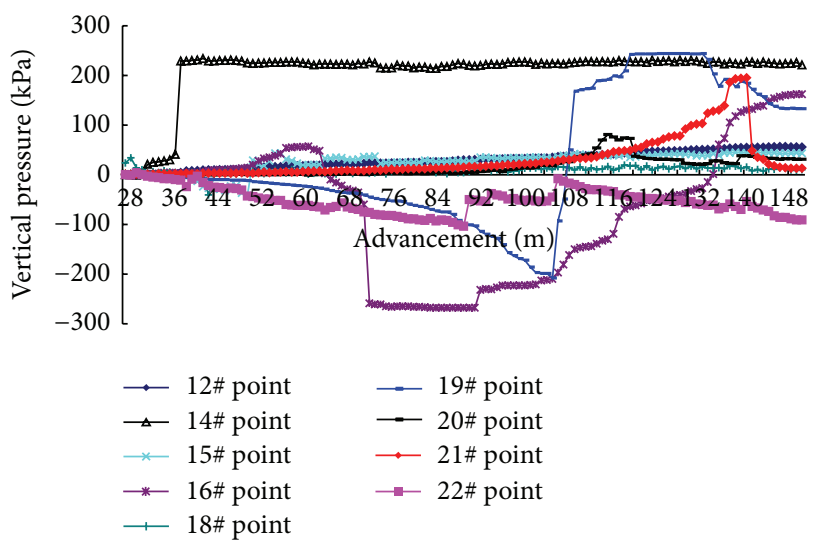

(b) Distance to the roof is $15 \mathrm{~m}$

FIgURE 7: Vertical stress variation along with face advancement.

Figure 8 shows the effect of existence of KSIR on the distribution of abutment pressure when advancing $50 \mathrm{~m}$. Figure 9(a) shows that the existence of KSIR increases the peak of abutment pressure, but it does not much affect the distance between peak stress position and coal wall and the influence scope of peak stress.

The thickness of KSIR in the model is $6 \mathrm{~m}$. Three different positions of KSIR are simulated, and they are KSIR in the lower part of immediate roof (distance to the top of coal seam is $0 \mathrm{~m}$ ), KSIR in the middle part of immediate roof (distance to the top of coal seam is $6 \mathrm{~m}$ ), and KSIR in the upper part of immediate roof (distance to the top of coal seam is $12 \mathrm{~m}$ ). Face advancement is $50 \mathrm{~m}$. The distribution of abutment pressure is shown in Figure 8. According to Figure 9(b), (1) the lower the KSIR position is, the larger the peak of abutment pressure is and the smaller the distance between peak position and coal wall is; (2) if KSIR is in the lower part of immediate roof, there are no soft layers acting as cushion layer between KSIR and coal seam when extracting the coal seam. Thus, the distribution of abutment pressure shows high-low oscillation because of KSIR break. Therefore, when extracting these coal seams, support should have antidynamic impact ability with certain yielding support columns.

Three different hardness coefficients $(f=3, f=9$, and $f=15$ ) of KSIR models are simulated when KSIR is in the middle part of immediate roof. The distribution of abutment pressure under these three conditions is shown in Figure 9(c). With the increase of hardness coefficient, the peak of abutment pressure and the affected scope of abutment pressure increased. This phenomenon is in accord with site circumstance that the harder the roof is, the greater the strata behaviors are.

Three different thicknesses ( $3 \mathrm{~m}, 6 \mathrm{~m}$, and $12 \mathrm{~m}$ ) of KSIR models are simulated when KSIR is in the middle part of immediate roof. The distribution of abutment pressure under these three conditions is shown in Figure 9(d). With the increase of thickness, the peak of abutment pressure and the affected scope of abutment pressure increased. When 
TABLE 3: Mechanical properties of numerical model.

\begin{tabular}{|c|c|c|c|c|c|c|}
\hline Coal and rock mass & $\begin{array}{c}\text { Bulk modulus } \\
K / \mathrm{GPa}\end{array}$ & $\begin{array}{c}\text { Shear modulus } \\
\text { G/GPa }\end{array}$ & $\begin{array}{c}\text { Density } \\
d /{\mathrm{kg} \cdot \mathrm{m}^{-3}}\end{array}$ & $\begin{array}{l}\text { Friction } \\
\text { angle }^{\circ}\end{array}$ & $\begin{array}{l}\text { Cohesive } \\
\text { force/MPa }\end{array}$ & $\begin{array}{c}\text { Tensile } \\
\text { strength/MPa }\end{array}$ \\
\hline Overlying rock & 3 & 2.3 & 2200 & 30 & 2 & 2 \\
\hline Main roof & 10.1 & 8.2 & 2700 & 33 & 5.9 & 3 \\
\hline KISR & 5.1 & 4.2 & 2500 & 33 & 3.9 & 3 \\
\hline Immediate roof & 1.85 & 1.64 & 2000 & 24 & 1.1 & 1.19 \\
\hline 15\# coal seam & 2.05 & 1.84 & 1400 & 25 & 1.85 & 0.89 \\
\hline Floor & 10 & 8 & 2500 & 30 & 7 & 5 \\
\hline
\end{tabular}

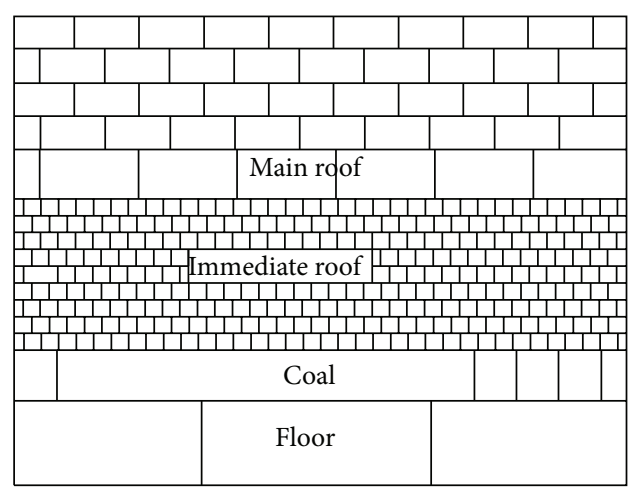

(a) Without KSIF

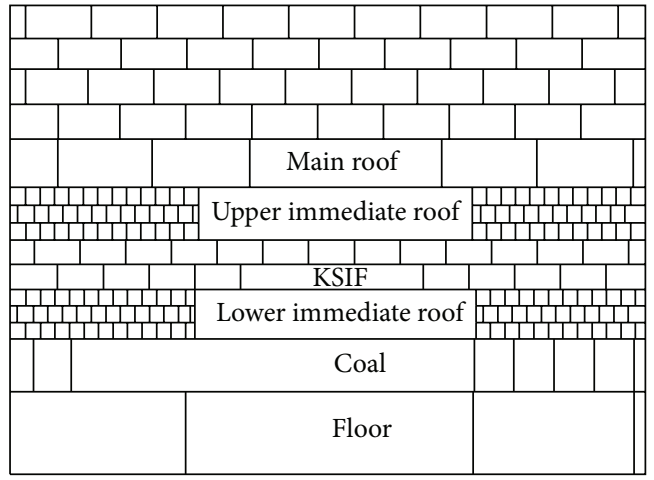

(b) With KSIF

FIGURE 8: Simulation model of the exsitence of KSIR.

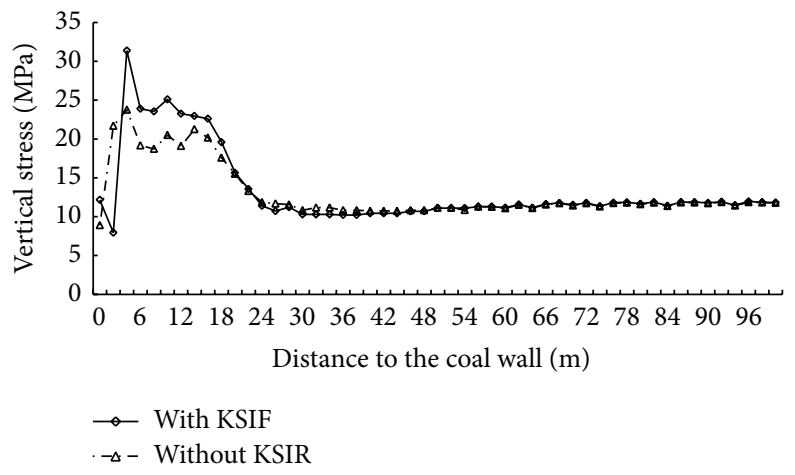

(a) With or without KSIR

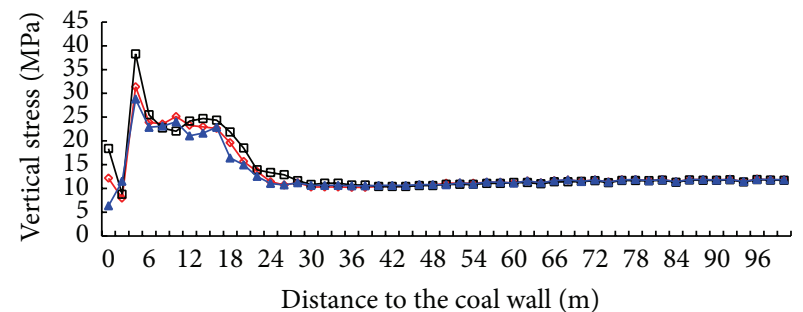

$\begin{aligned} & \diamond f=9 \\ & \square f=15\end{aligned} \rightarrow f=3$

(c) Hardness of KSIR

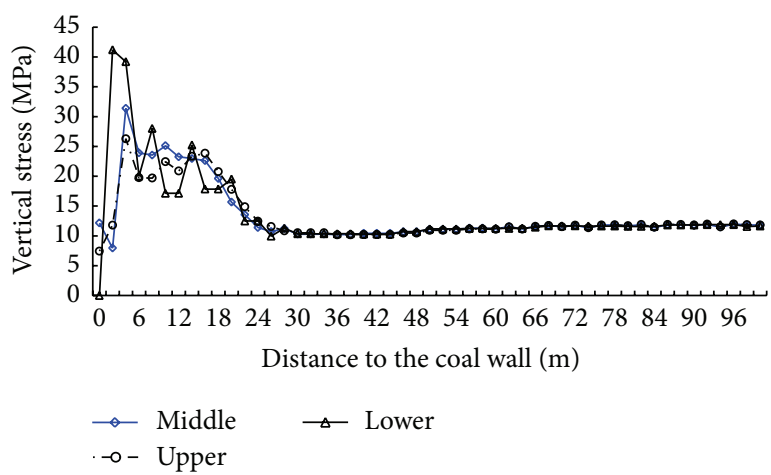

(b) Position of KSIR

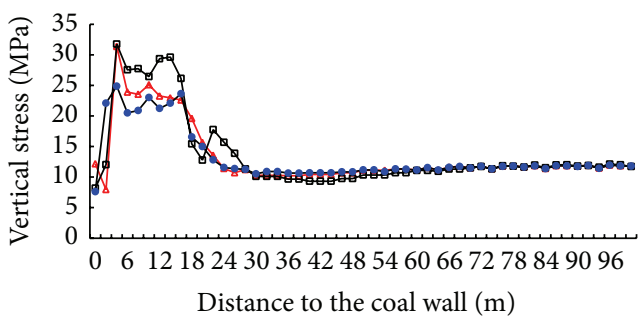

$\begin{array}{ll}\triangle 6 \mathrm{~m} & \rightarrow 3 \mathrm{~m} \\ \square & 12 \mathrm{~m}\end{array}$

(d) Thickness of KSIR

FIGURE 9: Effect on distribution of abutment pressure of KSIR. 


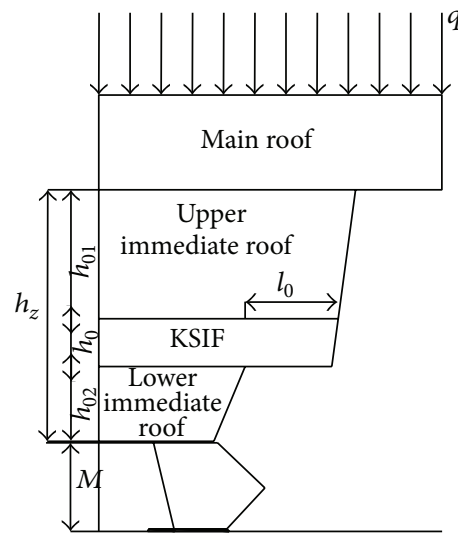

(a)

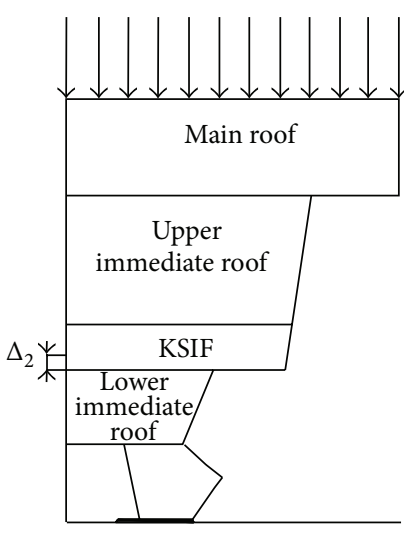

(b)

FIgURE 10: Dynamic load calculation model of KSIR.

the thickness of KSIR is $12 \mathrm{~m}$, abutment pressure shows oscillation distribution.

\section{Control of Dynamic Effect in FMMLMH Face}

"Suspended roof" tends to be formed in FMMLMH face because of the existence of hard and thick KSIR. KSIR forms the cantilever beam structure. The break of KSIR and main roof can easily form the bilayer structure "CantileverMasonry beam." The instability of cantilever beam structure causes dynamic impact of support; thus support accidents such as support pushed down can easily happen. Therefore, determination of support work load in FMMLMH should take KSIR dynamic impact into consideration, as is shown in Figure 10.

Take the most dangerous circumstance; for example, the crack of KSIR and main roof is on the coal wall. When KSIR breaks, from the position which the distance to the lower immediate roof is $\Delta_{2}$, KSIR does work to the lower immediate roof and support system. Under the dynamic impact, the sinkage of the lower immediate roof and support system is $\Delta_{1}$; load $(P)$ imposed on the support is

$$
P=Q_{1}+Q_{2}+Q_{3}
$$

where $Q_{1}$ is static load of immediate roof, $\mathrm{kN} ; Q_{2}$ is addition load of main roof, $\mathrm{kN} ; \mathrm{Q}_{3}$ is dynamic load of $\mathrm{KSIR}, \mathrm{kN}$.

3.1. Static Load of Immediate Roof. Static load of immediate roof $\left(Q_{1}\right)$ is the immediate roof strata load beneath the KSIR; $Q_{1}$ is calculated with the following:

$$
Q_{1}=\gamma B l_{k} h_{01},
$$

where $h_{01}$ is the thickness of immediate roof strata beneath the KSIR, $m$.

3.2. Addition Load of Main Roof. As the position of main roof is relatively far from the support and there are soft strata in main roof which can absorb energy, these soft strata have poor ability of transporting energy. Thus, most of energy generated during the break of main roof has been absorbed. The addition load of main roof $\left(Q_{2}\right)$ is generally calculated with multiple immediate roof loads. $Q_{2}$ can be represented by

$$
Q_{2}=(n-1) \gamma l_{k} B h_{z}
$$

3.3. Dynamic Load of KSIR. Dynamic impact is a complicated physical process. Many aspects should be taken into account such as short action time, concentration and consumption of sound, and thermoenergy; if the dynamic impact is precisely analyzed, propagation effect of stress wave should be also considered. Thus, the calculation process is quite complicated and is difficult to the actual application. Therefore, we simplified several conditions as follows. (1) The time between KSIR breaks and upper immediate roof breaks is 0 . (2) There is no springback when the broken KSIR touches the lower immediate roof. (3) There is no dissipation energy of sound and heat during impact process; the impact transports instantly through impacted body, and the impacted body obeys Hook's law.

Based on the law of conservation of mechanical energy, kinetic energy $E_{k}$ and potential energy $E_{p}$ during the impact of KSIR break are all transferred into deformation energy $V$ of the lower immediate roof. Consider

$$
E_{k}+E_{p}=V
$$

The impact process does not affect the overlying movement above main roof; thus these overlying loads can be neglected. When lower immediate roof reaches its lowest position, the shrinking potential energy of KSIR is

$$
E_{p}=Q_{k z}\left(\Delta_{1}+\Delta_{2}\right),
$$

where $Q_{k z}$ is the weight of KSIR and upper immediate roof.

Initial velocity and final velocity of lower immediate roof during dynamic impact of KSIR break are the same, at 0 . One has

$$
E_{k}=0 \text {. }
$$


As the impacted body obeys Hook law, the increased strain energy $V$ can be represented as

$$
V=\frac{1}{2} Q_{3} \Delta_{2}
$$

For the lower immediate roof, the relation between $Q_{3}$ and $\Delta_{2}$ is

$$
Q_{3}=\frac{E A}{h_{01}} \Delta_{2},
$$

where $E$ is elastic modulus of the lower immediate roof, $\mathrm{MPa}$; $A$ is hang areas of the lower immediate roof, $\mathrm{m}^{2}$.

Combined with (10), (11), (12), and (13), (9) can be transformed into

$$
\frac{E A}{2 h_{01}} \Delta_{2}^{2}-Q_{k z} \Delta_{2}-Q_{k z} \Delta_{1}=0 .
$$

Under the impact of KSIR break and static load of upper immediate roof, compression of the lower immediate roof $\left(\Delta_{0}\right)$ is

$$
\Delta_{0}=\frac{Q_{k z} h_{01}}{E A}
$$

Combining (14) with (15),

$$
\Delta_{2}^{2}-2 \Delta_{0} \Delta_{2}-2 \Delta_{0} \Delta_{1}=0 .
$$

Solve the $\Delta_{2}$ and neglect the negative root as follows:

$$
\Delta_{2}=\Delta_{0}\left(1+\sqrt{1+\frac{2 \Delta_{1}}{\Delta_{0}}}\right) .
$$

Combining (15) and (17) with (13),

$$
Q_{3}=Q_{k z}\left(1+\sqrt{1+\frac{2 \Delta_{1}}{\Delta_{0}}}\right) .
$$

Label the $C_{d}$ as

$$
C_{d}=1+\sqrt{1+\frac{2 \Delta_{1}}{\Delta_{0}}} .
$$

$C_{d}$ is considered as the impact dynamic load coefficient $[15,16]$; it means the increased load multiple of the impacted body during the roof descending process.

Combining (7), (8), (18), and (19) with (6),

$$
P=\gamma B\left[h_{01} l_{k}+(n-1) h_{z} l_{k}+C_{d}\left(h_{z}-h_{01}\right)\left(l_{0}+l_{k}\right)\right],
$$

where $l_{0}$ is the hanging length of KSIR.

3.4. Discussion. Based on (19), when $\Delta_{0}=0.2 \mathrm{~m}$, the relation between $C_{d}$ and $\Delta_{1}$ is shown in Figure 11(a); when $\Delta_{1}=0.1 \mathrm{~m}$, the relation between $K_{d}$ and $\Delta_{0}$ is shown in Figure 11(b). According to Figure 10, dynamic impact can be alleviated by reducing the descending height of broken KSIR and by increasing the compressibility of support column.
In field practice, increasing the setting load can reduce the separation between the lower part of immediate roof and KSIF; if there is no separation at all, $\Delta_{1}=0$ and $C_{d}=2$.

Actually, part of the impact energy is consumed because of the existence of the lower part of immediate roof and the compressible elastic characteristic of support. Thus, dynamic impact is alleviated. Generally, the value of $C_{d}$ is $1 \sim 2$. The harder the KSIF and the closer the distance to the support are, the greater the dynamic impacts of the broken KSIR are, and vice versa.

(1) Effect of the Hanging Length of KSIF. Based on (20), the relation between support force and the hanging length of KSIR is shown in Figure 11 when $l_{k}=5.5 \mathrm{~m}, h_{01}=6 \mathrm{~m}$, $h_{z}=15 \mathrm{~m}, n=1.5, \gamma=25 \mathrm{kN} / \mathrm{m}^{3}$, and $B=1.75 \mathrm{~m}$.

Figure 12 indicates that, with the increase of $l_{0}$, dynamic impact to the lower part of immediate roof increased; thus greater support resistance is needed. When the hanging length is $10 \mathrm{~m}$, support with working resistance over $10000 \mathrm{kN}$ can also be crushed. Therefore, hanging length should be controlled to protect support under the circumstances that the roof is relatively hard or the immediate roof is thin.

\section{(2) Effect of the Position of KSIF}

(a) When $h_{z}=h_{01}$, KSIF is the main roof, which means there are no hard strata in immediate roof. Support work force is calculated with (7).

(b) When $h_{01}=0$, the lower part of immediate roof does not exist. Supports contact with KISR directly, which equals mining under hard roof. Equation (20) can be transformed into

$$
P=\gamma B h_{z}\left[(n-1) l_{k}+C_{d}\left(l_{0}+l_{k}\right)\right]
$$

Equation (21) shows that the support load is mainly affected by the hanging length of KSIF.

(c) When $h_{01}=m h_{z}(0<m<1)$, this means KSIF exist in immediate roof. Consider

$$
P=\gamma B h_{z}\left[m l_{k}+(n-1) l_{k}+C_{d}(1-m)\left(l_{0}+l_{k}\right)\right]
$$

Equation (22) shows that the support load is mainly affected by the position and the hanging length of KSIF.

\section{Application}

Based on the working conditions of No. 15104 working face of Shijiazhuang coal mine, support work force can be achieved $(P=7382.8 \mathrm{kN})$ according to $(20)$ when $l_{k}=5.5 \mathrm{~m}, l_{0}=2 \mathrm{~m}$, $l_{z}=15 \mathrm{~m}, h_{01}=6, n=1.5, \gamma=25 \mathrm{kN} / \mathrm{m}^{3}$, and $B=1.75 \mathrm{~m}$. ZY8000/26/56 shield hydraulic support is adopted in the face. The mine pressure behavior is shown in Figure 13.

Conclusions can be drawn from Figure 12 that (1) the first weighing steps in lower part, middle part, and upper part of working face are $36 \mathrm{~m}, 34 \mathrm{~m}$, and $38 \mathrm{~m}$; the average periodic weighting intervals are $17 \mathrm{~m}, 17 \mathrm{~m}$, and $19 \mathrm{~m}$; the average 


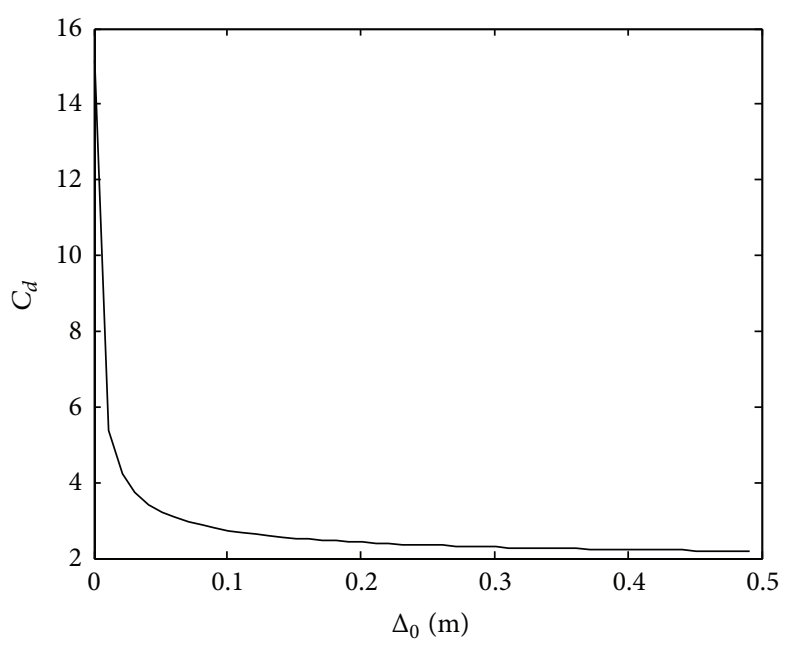

(a)

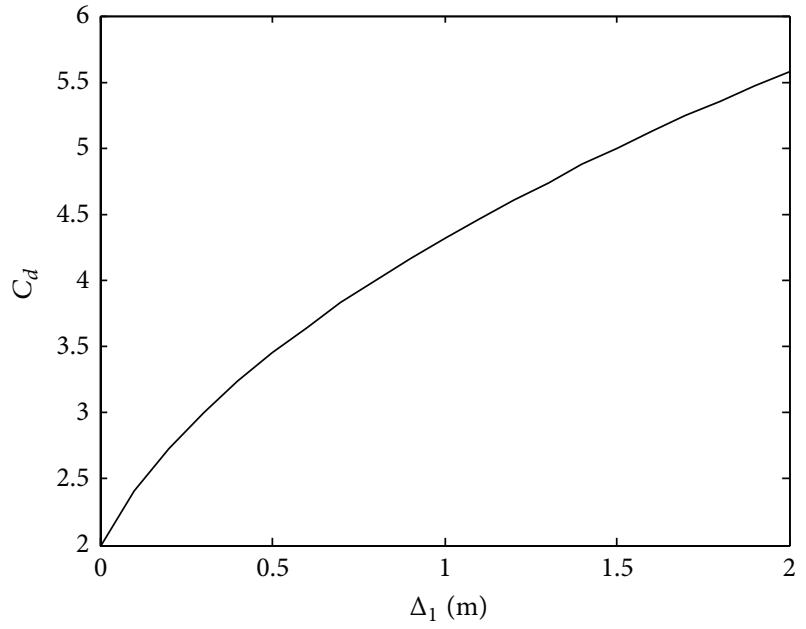

(b)

Figure 11: The relation between $C_{d}$ and $\Delta_{1}, \Delta_{0}$.

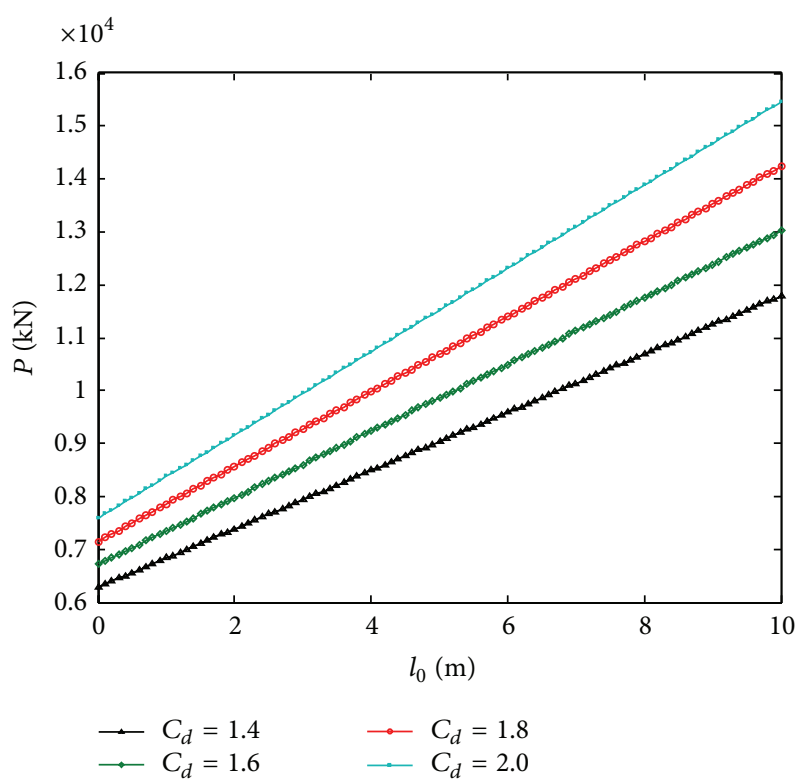

Figure 12: The relation between $P$ and $l_{0}, C_{d}$.

weighing distances are $4.3 \mathrm{~m}, 3.7 \mathrm{~m}$, and $3.8 \mathrm{~m}$; the average dynamic load factors are $1.43,1.53$, and 1.48 , respectively; (2) the average dynamic load of the working face is 1.48 . Overall, the selection of support in this face is reasonable although there are some safety valves in upper face supports activated due to roof fall caused by the crushed gas tail roadway.

\section{Conclusion}

(1) Large mining and caving height are the basic characteristics of FMMLMH face. The strata between masonry beam structure and coal seam are defined as immediate roof; the main roof is the strata which can form the stable structure above the immediate

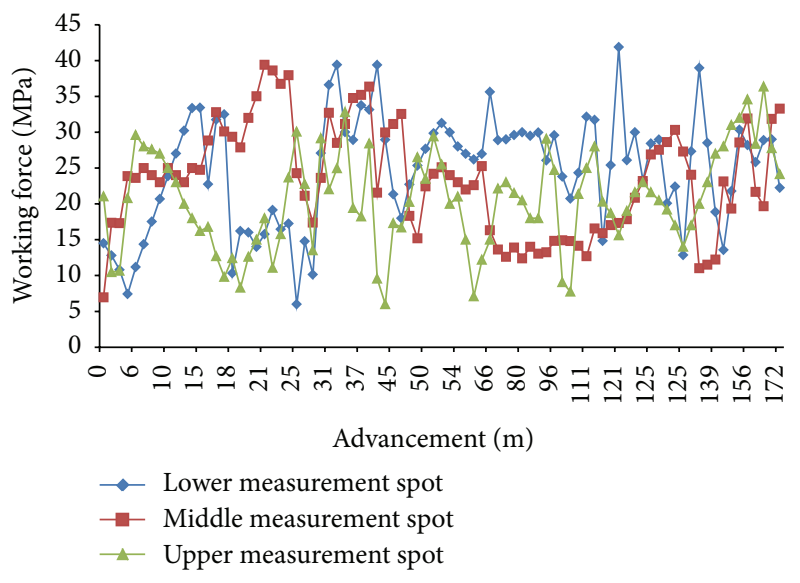

FIGURE 13: Support work force of No. 15104 face.

roof. This paper defines KSIF as the strata which can control the caving of the immediate roof and also puts forward the discrimination methods and procedures.

(2) KSIR controls the movement of the upper immediate roof and has dynamic impact on the lower part of immediate roof when it breaks. The dynamic impact increases along with the increase of the thickness and hardness of KSIR and the decrease of the distance to the working seam.

(3) With the existence of KSIR, KSIR and main roof can easily form the bilayer structure "Cantilever-Masonry beam" in FMMLMH face. Support work load under this condition is affected by the position, thickness, and hardness of KSIR. Based on (20), the above achievements are successfully applied in the support selection in No. 15104 face of Shijiazhuang coal mine. 


\section{Conflict of Interests}

The authors declare that there is no conflict of interests regarding the publication of this paper.

\section{Acknowledgments}

Financial support for this work is provided by the Priority Academic Program Development of Jiangsu Higher Education Institutions and the Fundamental Research Funds for the Central Universities (2014QNB32).

\section{References}

[1] P. Wu, H. Chen, and R. Long, "Relationship between coal output and safety in China," Disaster Advances, vol. 5, no. 4, pp. 551-556, 2012.

[2] X. P. Yuan, "The characters and trend of accidents in the coal mining in China," Disaster Advances, vol. 5, no. 4, pp. 866-869, 2012.

[3] S. H. Tu, Y. Yuan, Z. Yang, X. T. Ma, and Q. Wu, "Research situation and prospect of fully mechanized mining technology in thick coal seams in China," Procedia Earth and Planetary Science, vol. 1, no. 1, pp. 35-40, 2009.

[4] J. F. Ju and J. L. Xu, "Structural characteristics of key strata and strata behaviour of a fully mechanized longwall face with 7.0m height chocks," International Journal of Rock Mechanics and Mining Sciences, vol. 58, pp. 46-54, 2013.

[5] Y. Yuan, S.-H. Tu, Y. Wang, X.-T. Ma, and Q. Wu, "Discussion on key problems and countermeasures of fully mechanized mining technology with high mining height," Coal Science and Technology, vol. 38, no. 1, pp. 4-8, 2010.

[6] J. Xu and J. Ju, "Structural morphology of key stratum and its influence on strata behaviors in fully-mechanized face with super-large mining height," Chinese Journal of Rock Mechanics and Engineering, vol. 30, no. 8, pp. 1547-1556, 2011.

[7] Y. Yong, Stability Control Mechanism of Support-Surrounding Rocks at Fully Mechanized Mining Face with Great Cutting Height, China University of Mining \& Technology, Xuzhou, China, 2011.

[8] P.-L. Gong and Z.-M. Jin, "Study on the structure characteristics and movement laws of overlying strata with large mining height," Journal of the China Coal Society, vol. 29, no. 1, pp. 711, 2004.

[9] Y.-P. Fu, X.-M. Song, P.-W. Xing, G.-C. Yan, and Z.-J. Li, "Stability analysis on main roof key block in large mining height workface," Journal of the China Coal Society, vol. 34, no. 8, pp. 1027-1031, 2009.

[10] H.-J. Hao, J. Wu, Y. Zhang, and Z.-B. Yuan, "Balance structure of main roof and its action to immediate roof in large cutting height workface," Journal of the China Coal Society, vol. 29, no. 2, pp. 137-141, 2004.

[11] C. Y. Liu and M. G. Qian, "Stability and control of immediate roof of fully mechanized coal face," in Proceedings of the International Conference on Ground Control in Mining, pp. 123127, The University of West Virgina, Morgantown, WVa, USA, 1990.

[12] L.-M. Dou, X.-Z. Zou, S.-G. Cao et al., Surrounding Rock Control of Coal Mine, China University of Mining and Technology Press, Xuzhou, China, 2010.
[13] H.-Z. Zhao and Q.-S. Song, "Development of hydraulic support for super great mining height," Journal of Mining \& Safety Engineering, vol. 27, no. 3, pp. 265-269, 2007.

[14] M.-G. Qian, X.-X. Miao, J.-L. Xu et al., Theory of Key Strata in Ground Control, China University of Mining and Technology Press, Xuzhou, China, 2003.

[15] J.-C. Wang, Theory and Technology of Thick Coal Seam Mining, Metallurgical Industry Press, Beijing, China, 2009.

[16] X.-R. Jia, Ground Control, China University of Mining and Technology Press, Xuzhou, China, 2011. 

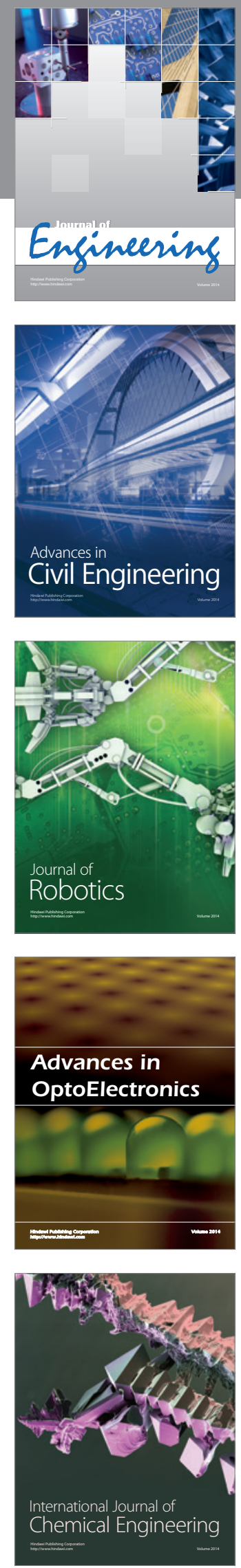

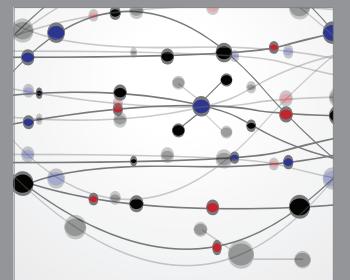

The Scientific World Journal
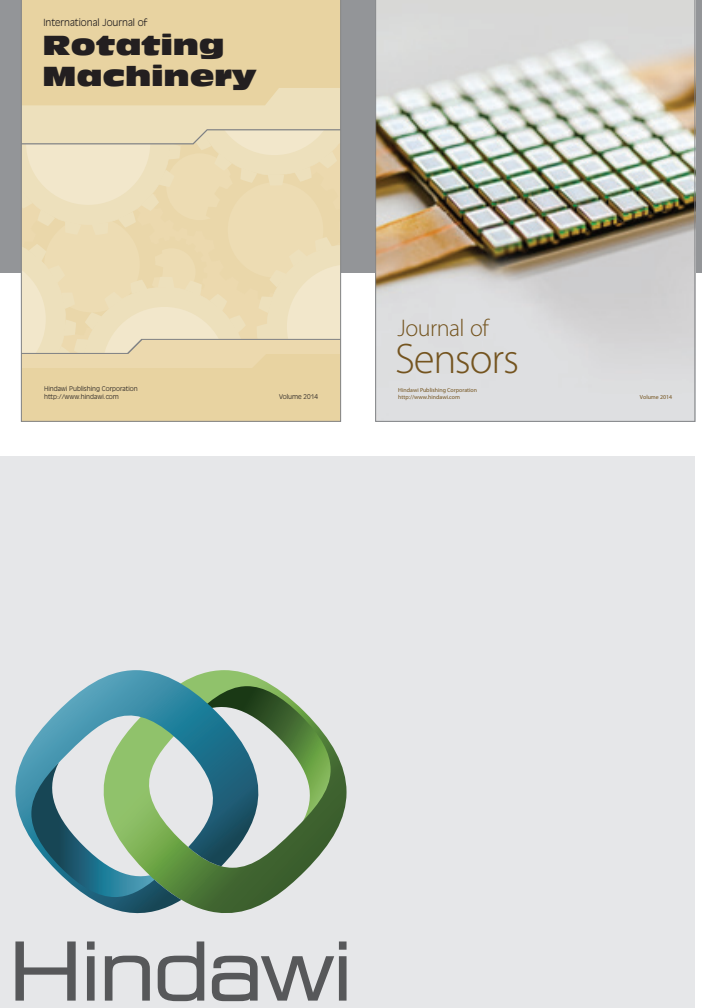

Submit your manuscripts at http://www.hindawi.com
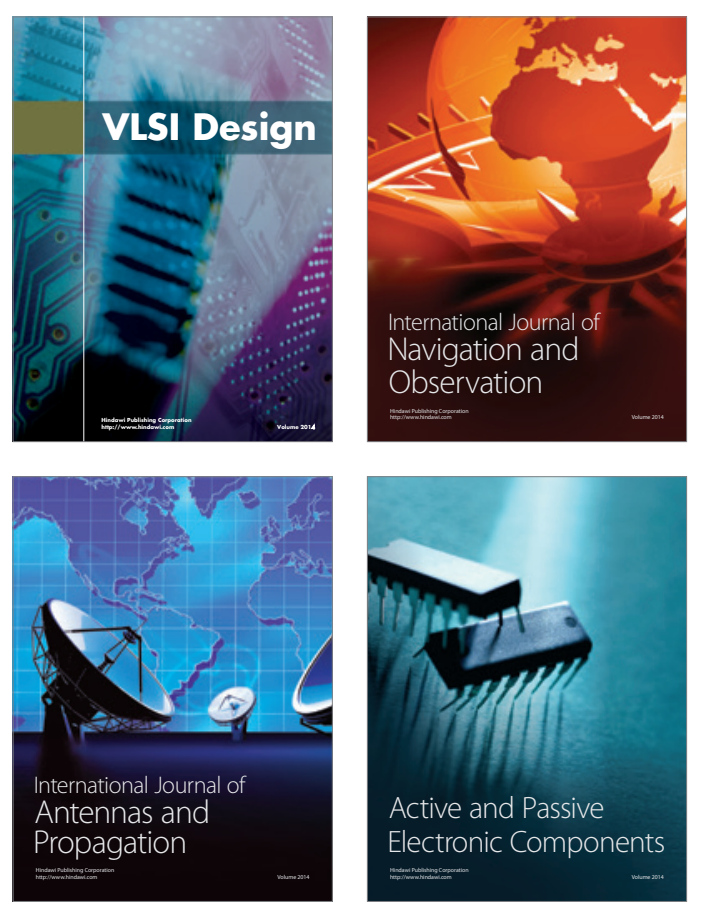
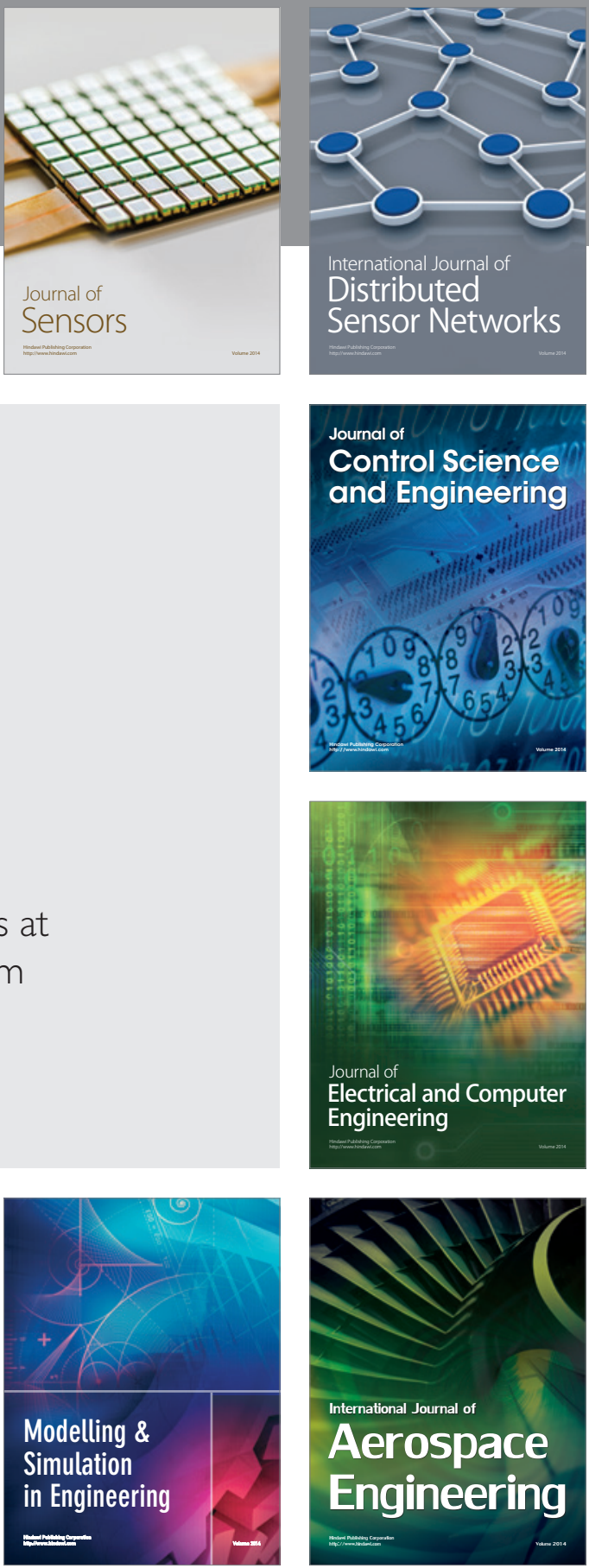

Journal of

Control Science

and Engineering
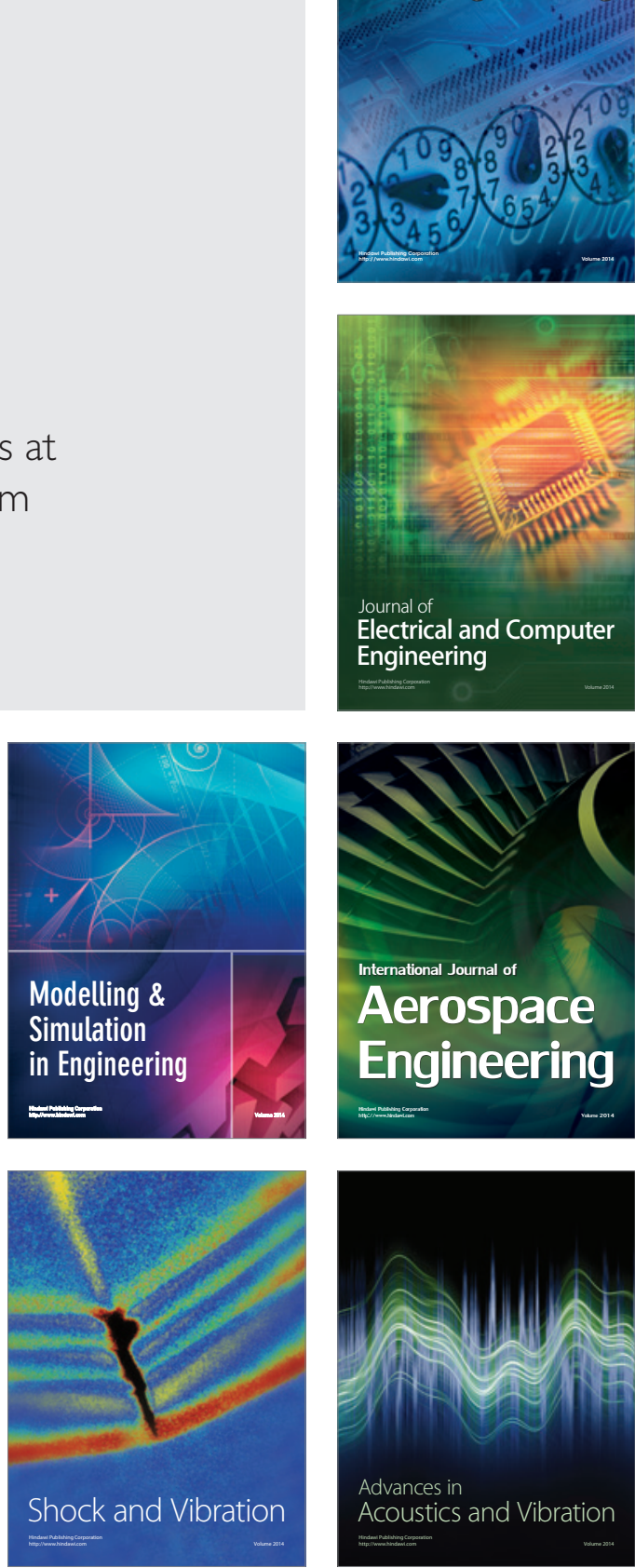